\title{
Wetsvoorstel collectieve schadevergoedingsactie: een oplossing
voor welk probleem ook alweer?
}

\author{
Prof. mr. I.N. Tzankova*
}

\begin{abstract}
1. Inleiding
De afwikkeling van massaschade geniet belangstelling in binnen- en buitenland, onder belangenbehartigers, beleidsmakers en binnen de rechterlijke macht. De aandacht voor massaschadeafwikkeling is terecht. Als gevolg van de industrialisatie, globalisering en de ontwikkelingen op het terrein van social media ${ }^{1}$ hebben we steeds vaker met massaschade te maken. Van een trend is geen sprake, massaschade blijft. ${ }^{2}$ De manier waarop een rechtsstelsel de procedurele afwikkeling van massaschade heeft geregeld, heeft impact op het rechtsgevoel en de rechtsbeleving van rechtzoekenden over de kwaliteit van de toegang tot het recht in hun jurisdictie. Inmiddels wordt op steeds meer plaatsen onderkend dat een rechtsstelsel dat de toegang tot het recht serieus neemt een structurele wettelijke voorziening nodig heeft om efficiënt, effectief en rechtvaardig met massaschade om te gaan, waarbij de toegang tot het recht voor eisers en gedaagden gewaarborgd is. Ad-hocoplossingen volstaan niet. Het denken via de gebaande procedurele paden van bilaterale conflictbeslechting volstaat evenmin. De afwikkeling van massaschade kent een eigen dynamiek en het procesrecht dient deze in acht te nemen.
\end{abstract}

Het wetsvoorstel ${ }^{3}$ collectieve schadevergoedingsactie (hierna: het wetsvoorstel), dat op 15 november 2016 werd ingediend bij de Tweede Kamer, past in deze lijn. De directe aanleiding daarvoor vormde de motie Dijksma uit 2011, waarin de wens werd geuit om de mogelijkheden tot collectief schadeverhaal in de wet te regelen teneinde de slagvaardigheid van het collectieve-actierecht te vergroten. ${ }^{4}$ Het momentum werd door een

Prof. mr. I.N. Tzankova is hoogleraar Global Dispute Resolution and Mass Claims aan Tilburg University en zelfstandig adviseur.

De auteur dankt Jan Vranken, Deborah Hensler, Jasminka Kalajdzic en Axel Halfmeier voor hun input.

1. D. Hensler, How economic globalisation is helping to construct a private transnational legal order, in: S. Muller e.a. (red.), The law of the future and the future of law, Oslo: Torkel Opsahl Academic EPublisher 2011, p. 249, te raadplegen via: www.fichl.org/fileadmin/fichl/documents/ FICHL_11_Web.pdf.

2. I.N. Tzankova, Hoe globaliseringsproof is het Nederlandse collectieve actierecht?, in: Collectieve acties (Preadviezen voor de Nederlandse Vereniging voor Burgerlijk Recht), Zutphen: Uitgeverij Paris 2015, p. 65 (65-94).

3. Kamerstukken II $2016 / 17,34608,2$,

4. Kamerstukken II $2011 / 12,33000$ XIII, 14. samenwerkende lobby van de meer gevestigde belangenbehartigers en advocaten van verweerders gebruikt om tevens een tweetal knelpunten van de huidige regeling te adresseren: de concurrerende belangenorganisaties met soms twijfelachtige governance $^{5}$ en het bereiken van finaliteit bij de massaschadeafwikkeling. ${ }^{6}$ Dat resulteerde in 2015 in een 'Aanbeveling van de Juristengroep', 7 die de basis vormde voor het wetsvoorstel. $^{8}$

Het wetsvoorstel beoogt schikken aantrekkelijker te maken door verbetering van de kwaliteit van collectieve belangenbehartigers, coördinatie van collectieve procedures en meer finaliteit. Om dit te bereiken wordt één regime voor alle collectieve acties geïntroduceerd, ongeacht of ze strekken tot vergoeding in geld of niet, en worden de ontvankelijkheidseisen voor belangenorganisaties aangescherpt op het punt van governance, financiering en representativiteit. De Claimcode, een zelfreguleringsinitiatief dat governanceverbetering van belangenorganisaties nastreeft, is wettelijk verankerd, financiële draagkracht wordt expliciet getoetst en er worden belangenorganisaties met een voldoende grote achterban verlangd. Tevens wordt er een scope rule geïntroduceerd die ervoor moet zorgen dat de collectieve vordering een voldoende nauwe band heeft met de Nederlandse rechtssfeer. Als meer partijen een collectieve vordering willen instellen voor dezelfde gebeurtenis of gebeurtenissen over soortgelijke feitelijke en rechtsvragen, wijst de rechter uit hun midden de meest geschikte aan als exclusieve belangenbehartiger (ebb) voor alle gedupeerden. Een openbaar register, waarin collectieve acties moeten worden gemeld, moet dit proces faciliteren. $\mathrm{Na}$ de aanwijzing van een ebb kunnen gedupeerden zich aan de procedure onttrek-

5. Zie ook W.H. van Boom \& F. Weber, Collectief procederen, WPNR 2017/7145, par. 3.2

6. R.M. Hermans, De oorzaken van het niet totstandkomen van collectieve schikkingen in massaschadezaken, in: M. Holtzer, A.F.J.A. Leijten \& D.J. Oranje (red.), Geschriften vanwege de Vereniging Corporate Litigation 2014-2015, Deventer: Wolters Kluwer 2015, p. 361-387.

7. De Juristengroep die de Aanbevelingen heeft opgesteld, bestaat uit Olav Haazen, Femke Hendriks, Niels Lemmers, Jurjen Lemstra, Daan Lunsingh Scheurleer en Brechje van der Velden.

8. Voor een kritische bespreking van wat de wetgever links heeft laten liggen, zie C.M.D.S. Pavillon \& D.G.J. Althoff, Wijze raad is halve daad of veel raad maar weinig baat?, MvV 2017, afl. 3, p. 104-115. 
ken door middel van opt-out. De uitspraak van Rechtbank Amsterdam, die bij uitsluiting bevoegd is om collectieve vorderingen te beoordelen, is vervolgens bindend voor alle benadeelden die niet zijn uitgestapt.

Het wetsvoorstel werd begin 2017 controversieel verklaard ${ }^{9}$ en belandde tijdelijk in de wetgevingsijskast in afwachting van de formatie van een nieuwe regering. Met de komst van Rutte III is het wetsvoorstel weer actueel. Hoewel er ook waardering is voor het wetsvoorstel, lijkt de kritische toon te domineren. ${ }^{10}$ Een aantal niet limitatief bedoelde bezwaren ter illustratie: het wetsvoorstel verzwaart onnodig de voorwaarden voor alle collectieve acties, en niet alleen voor die strekkende tot schadevergoeding, en gooit daarmee het kind met het badwater weg; ${ }^{11}$ de aanwijzing van een ebb leidt tot onwenselijke closed shop-winkelnering, ${ }^{12}$ nog daargelaten dat de rechterlijke macht niet op deze taak zit te wachten en zich geen raad weet met 'jury spelen in beauty contests'; ${ }^{13}$ en de opt-outregeling komt te vroeg in de procedure en is onvoldoende flexibel. ${ }^{14}$ Voorts menen sommigen dat met de huidige scope rule onvoldoende is gewaarborgd dat Nederland geen trekpleister wordt voor internationale massaschadegeschillen tegen in Nederland gevestigde ondernemingen. ${ }^{15}$ Nederland als trekpleister voor bilaterale handelsgeschillen is overigens prima, graag zelfs. ${ }^{16}$ De gedachte bij een groep is kennelijk dat strijdende buitenlandse bedrijven welkom zijn in de Nederlandse rechtszalen, zeker als ze meer griffierechten betalen, maar groepen buitenlandse consumenten en/of benadeelden van eventuele ongeoorloofde handelspraktijken van die bedrijven niet. ${ }^{17}$ Voor een meer gedetailleerde bespreking van het wetsvoorstel verwijs ik naar bijdragen elders. ${ }^{18}$ Ik beperk mij hier tot twee aspecten die tot nu toe onderbelicht zijn gebleven, terwijl zij naar mijn mening voor een goed begrip van het wetsvoorstel en de discussie daaromheen essentieel zijn, en veel van de kri-

9. Kamerstukken II 2016/17, 34707, 12.

10. O.a. E. Bauw \& S. Voet, Van stok achter de deur tot keurslijf? Een eerste verkenning van het wetsvoorstel tot invoering van een collectieve schadevergoedingsactie, NJB 2017, p. 244 e.v., M. de Vries, Voortmodderen met de massaclaims, Advocatenblad 2017, afl. 8, p. 50-53, W.H. van Boom, Wetsvoorstel richt zwaar geschut op alle collectieve acties (een blogbericht) en Van Boom \& Weber 2017. Milder: Pavillon \& Althoff 2017.

11. Bauw \& Voet 2017; Van Boom \& Weber 2017. Anders: Pavillon \& Althoff 2017, p. 106.

12. M.G. Faure \& L.T. Visscher, Een rechtseconomische visie op collectieve actie, in: Collectieve acties (Preadviezen voor de Nederlandse Vereniging voor Burgerlijk Recht), Zutphen: Uitgeverij Paris 2015, p. 7-64.

13. Een reactie van deelnemers aan het seminar 'Enforcement of consumer rights', dat Tilburg University en de ACM organiseerden op 11 september 2017.

14. Pavillon \& Althoff 2017, p. 113-114; Van Boom \& Weber 2017, par. 3.2 .3$.

15. M. van Wissen \& T.M. Welling, Afwikkeling van massaschade: het wetsvoorstel collectieve schadevergoedingsactie, Mededingingsrecht in de Praktijk 2017/81.

16. E. Bauw \& X. Kramer, Commercial Court is uitkomst voor complexe internationale handelszaken, FD 11 oktober 2017.

17. Er zijn schrijvers die vraagtekens plaatsen bij de juridische legitimiteit van de scope rule en zijn verenigbaarheid met het Europese recht: Pavillon \& Althoff 2017, p. 109-110.

18. O.a. Bauw \& Voet 2017, Pavillon \& Althoff 2017 en Van Boom \& Weber 2017. tiek in een context plaatsen. Ik behandel achtereenvolgens in paragraaf 2 de vrees voor 'US style litigation' en commercie bij privaatrechtelijke rechtshandhaving, die impliciet veel van de gemaakte keuzes en de strenge ontvankelijkheidsregels in het wetsvoorstel heeft gedicteerd, en in paragraaf 3 het gebrekkige begrip bij beleidsbepalers en het brede publiek van de economische realiteit van massaschade, hetgeen van directe invloed is op de effectiviteit van de voorgestelde collectieve-actieregeling. Ik rond in paragraaf 4 af met een samenvatting en een conclusie.

\section{Claimcultuur en commercie bij privaatrechtelijke rechtshandhaving}

\subsection{Waar gaat dit over?}

De vrees van de Europese en daarmee ook van menig nationale beleidsmaker en wetgever die een collectieve-actieregeling ontwerpen, is dat zij een voorstel formuleren dat zou kunnen leiden tot commerciële en daarmee verwerpelijke 'US style class actions'-praktijken en tot een verhoogde claimcultuur. Beleidsdocumenten, consultaties, witte en groene papers en aanbevelingen over collectieve-actieregelingen op Europees niveau bevatten overwegingen en beschouwingen die de lezers de geruststelling moeten geven dat het desbetreffende voorstel of regeling voldoende waarborgen bevat tegen 'US style litigation'. ${ }^{19}$ Wat daaronder precies wordt verstaan, wordt zelden eenduidig toegelicht, laat staan deugdelijk onderbouwd. Bij doorvragen blijkt dat vaak betrekking te hebben op de inmiddels legendarische 'ambulance chasers': letselschadeadvocaten van slachtoffers van medische kunstfouten of verkeersongevallen. In de context van collectieve acties wordt met 'US style litigation' doorgaans gedoeld op wat in de VS 'frivolous litigation' heet, die tot 'blackmail settlements' zou leiden. Dat betreft een beroep op de rechter voor het beslechten van kansloze of zwakke collectieve claims die de gedaagden door het grote volume zouden dwingen om te schikken vanwege het te vrezen reputatieverlies en de te verwachten hoge kosten van verdediging, zelfs van een 'gewonnen' zaak. ${ }^{20}$

Maar wat is een 'kansloze' of een 'zwakke' claim? Op welk moment beoordeel je dat? En is een dergelijke beoordeling eigenlijk wenselijk? Iets dat er aan het begin van een procedure zwak en kansloos uitziet, kan tot voortschrijdende inzichten leiden. Wij zijn juristen en, als het goed is, niet alleen betrokken bij het oplossen van echte problemen van echte cliënten, maar ook bij de rechtsontwikkeling, en wij willen bijdragen aan een rechtvaardigere samenleving. Een collectieve actie die

19. Een van de meer recente voorbeelden is Commission Recommendation of 11 June 2013 on common principles for injunctive and compensatory collective redress mechanisms in the Member States concerning violations of rights granted under Union Law (2013/396/EU), PbEU 2013, L 201.

20. Voor een uitgebreide oude, maar nog steeds actuele, Nederlandstalige bespreking van dit concept, zie I.N. Tzankova, Strooischade: een verkennend onderzoek naar een nieuw rechtsfenomeen (Allen Overy Onderzoeksreeks), Den Haag: Sdu Uitgevers 2005, p. 99-111 met verdere verwijzingen. 
gebaseerd is op een nieuwe aansprakelijkheidsgrondslag of -theorie zou volgens sommigen op voorhand als kansloos of zwak en dus 'frivolous' worden bestempeld, terwijl zij juist tot een baanbrekende, richtinggevende uitspraak of omkeer-jurisprudentie van de Hoge Raad kan leiden ten aanzien van een groot maatschappelijk probleem of thema. Baanbrekende Hoge Raad-uitspraken, zoals in Lindenbaum/Cohen (om maar een klassieker te noemen, zij het buiten de context van een collectieve actie), Dexia, Vie d'Or, World Online en vele andere, zijn van grote waarde voor de rechtspraktijk en rechtsontwikkeling, terwijl zij volgens de bovenstaande definitie als 'frivolous' zouden moeten worden aangemerkt en nooit het levenslicht hadden mogen zien. Een begrip als 'frivolous litigation' doet weinig recht aan deze waarden, nog daargelaten dat het Nederlandse procesrecht instrumenten heeft ontwikkeld om op een kostenefficiënte wijze met de behoefte aan rechtsontwikkeling en rechtszekerheid om te gaan, zonder dat partijen daar de dupe van worden. ${ }^{21}$

Van 'frivolous litigation' in de hiervoor bedoelde zin moet naar mijn mening het in Nederland gebezigde begrip 'claimcultuur', waarin de overmatigheid van de gang naar de rechter vooropstaat, worden onderscheiden, omdat daarin de gegrondheid van de claim die ten grondslag ligt aan deze gang niet relevant lijkt te zijn. ${ }^{22}$ In de visie van tegenstanders van claimcultuur lijkt het enkel te gaan om het niet overbelasten van de rechterlijke macht en de economie, ook niet met legitieme en valide claims. Als we ons in het fenomeen overmatig en ongegrond procederen en claimcultuur verdiepen, blijkt de werkelijkheid genuanceerder te zijn en moeten nog veel kennisgaten worden gedicht. ${ }^{23}$ Hoewel velen de 'frivolous litigation'-slogan blijven bezigen, neemt slechts een enkeling de moeite om dit concept te ontrafelen en op zijn waarde te schatten.

\subsection{De werkelijkheid blijkt genuanceerder}

Het empirische onderzoek naar claimcultuur in Nederland is schaars, maar voor zover er enige empirische studies zijn, onderschrijven zij het bestaan van een claimcultuur en 'frivolous litigation' niet. ${ }^{24}$

21. Het instrument van art. $392 \mathrm{Rv}$ (prejudiciële vragen aan de Hoge Raad) is het middel bij uitstek om claims die elke rechtsgrond zouden ontberen en niet tot nieuwe baanbrekende jurisprudentie leiden tijdig te weren.

22. 'Een cultuur waarin burgers elkaar veelvuldig en voor hoge bedragen in juridische zin aanspreken ter vergoeding van geleden schade, zonder dat dit overigens in alle gevallen hoeft te leiden tot een juridische procedure'; zie voor een beschouwing van dit begrip in de Nederlandse context o.a. B. van Hattum, De afwikkeling van zorgplichtclaims (diss. Amsterdam UvA), 2017, par. 7.2.2 en T. Hartlief, Leven in een claimcultuur. Wie is er bang voor Amerikaanse toestanden? (oratie Maastricht), 2005.

23. J.M. Vermolen \& W.H. van Boom, Wetgeving en claimcultuur: rationeel proces of politiek ritueel?, NTBR 2017/35.

24. I. Tillema, Commerciële motieven in privaatrechtelijke collectieve acties: olie op het vuur van de claimcultuur?, AA 2016, p. 337 e.v., E.P.M. Vermeulen \& D.A. Zetzsche, The use and abuse of investor suits: An inquiry into the dark side of shareholder activism, European Company and Financial Law Review (7) 2010, afl. 1; TILEC Discussion Paper No. 2010-001; CBC-RPS Paper No. 1/2010, te raadplegen via: ssrn.com/ abstract $=1428901$.
Indien we het fenomeen 'frivolous litigation' ook naar Amerikaanse objectieve wetenschappelijke maatstaven beschouwen en de feitelijke ofwel empirische gegrondheid daarvan nader onderzoeken, moeten we tot de conclusie komen dat een 'frivolous litigation'-explosie ook daar niet vast te stellen is. Daar zijn vooraanstaande Amerikaanse wetenschappers die de Amerikaanse 'class actions' sinds jaar en dag volgen, onderzoeken en becommentariëren het over eens: ${ }^{25}$

'As a result of the PSLRA, recent Supreme Court decisions, and recently tightened class certification standards, the truly "frivolous" securities class action is today relatively rare - possibly even a mythic creature of folklore, like the unicorn, in that it is much discussed, but seldom objectively observed. ${ }^{26}$ (cursivering IT)

\section{En verder:}

'This assertion is based on three assumptions about U.S. class actions: first, that the current class action regime produces a host of frivolous class actions that defendants are forced to settle because of their in terrorem effect; second, that class action jurisprudence enables easy access to courts for frivolous class claims; and third, that litigation investors' business models will favor frivolous claims. The available empirical data do not support the first assumption about the current regime, and recent U.S. Supreme Court jurisprudence as well as the economics of third-party litigation financing militate against a flood of frivolous class actions going forward. ${ }^{27}$ (cursivering IT)

Mede door het door de Amerikaanse wetgever stellen van zwaardere eisen aan de selectie van de belangenbehartiger bij beleggingsschade (bijvoorbeeld: de belegger met de grootste schade) of aan de inhoudelijke onderbouwing van vorderingen (via summary judgements) is van lichtvaardig ingestelde 'class action claims' geen sprake. Hierbij verdient aantekening dat in de Amerikaanse procedurele context het uitbrengen van een dagvaarding in het algemeen relatief eenvoudig is, zeker in vergelijking met de Nederlandse dagvaardingstraditie, en er geen systeem van een proceskostenveroordeling van de verliezende

25. Dit betreft overigens een bevestiging van een onderzoek dat ik reeds in 2005 afrondde: Tzankova 2005. De situatie is derhalve ruim tien jaar later onveranderd.

26. J. Coffee, Accountability and competition in securities class actions: Why 'exit' works better than 'voice', Cardozo Law Review (30) 2008, p. 407-444, litigation-essentials.lexisnexis.com/webcd/app?action= DocumentDisplay\&crawlid $=1 \&$ doctype $=$ cite $\&$ docid $=30+$ Cardozo $+\mathrm{L}$ + Rev. $+407 \&$ srctype $=$ smi\&srcid $=3 \mathrm{~B} 15 \& \mathrm{key}=6349 \mathrm{ad} 9 \mathrm{~d} 81 \mathrm{~b} 8662799 \mathrm{fb}$ 5babccf671a8. Zie ook L. McMillian, The nuisance settlement 'problem': The elusive truth and a clarifying proposal, American Journal of Trial Advocacy (31) 2007, p. 221 e.v., te raadplegen via: ssrn.com/ abstract $=1009289$.

27. D.R. Hensler, Third-party financing of class action litigation in the United States: Will the sky fall?, DePaul Law Review 2014, p. 510. Dit beeld is in de laatste tien jaar overigens niet gewijzigd. In mijn strooischadeonderzoek in 2005 naar 'blackmail settlements' en 'frivolous litigation' in de Amerikaanse context kwam ik reeds tot de conclusie dat daarvan, naar objectieve maatstaven, niets bleek. 
partij geldt, terwijl het vooral andere kenmerken van het Amerikaanse rechtssysteem zijn, zoals een uitgebreide discovery, punitive damages en jury trials, die de rechtspleging daar kostbaar maken. Kenmerken die losstaan van collectieve acties en in Europa, en zeker in Nederland, ontbreken.

Tot slot verdient een andere recente publicatie over de beruchte 'US litigious society', of beter gezegd: het ontbreken daarvan, van een vooraanstaande Amerikaanse wetenschapper vermelding:

'Why do Americans seem to sue at the slightest provocation? The answer may surprise you: we don't! (...) The question is not why Americans sue but why we don't sue more often, and the answer can be found in how we think about injury and personal responsibility. ${ }^{28}$

Cijfers gepubliceerd in 2011 door het Center for Justice Democracy van New York University zijn in lijn hiermee. ${ }^{29}$ Slechts $10 \%$ van de Amerikanen die letselschade oplopen, klagen daarover bij de veroorzaker en slechts $2 \%$ van deze $10 \%$ gaat over tot het instellen van een schadevergoedingsactie. Onrechtmatige-daadsacties (tort) beslaan slechts $4,4 \%$ van alle civiele rechtszaken en dit percentage is al jaren aan het dalen. Tussen 1999 en 2008 zijn de onrechtmatige-daadsacties in de VS zelfs afgenomen met liefst 25\%. Punitive damages awards worden zelden toegewezen.

\subsection{De retoriek van de US Chamber of Commerce}

Waar komt de hardnekkige perceptie van 'frivolous class actions' en de 'American litigious society' vandaan? Europese en nationale beleidsmakers stellen deze niet ter discussie, het zal waar zijn. Nader onderzoek toont aan dat de negatieve beeldvorming en stigmatisering van privaatrechtelijke handhaving het resultaat zijn van een jarenlange, zorgvuldig geplande en uitgevoerde pr-campagne van de Amerikaanse businesslobby, die niet tot de landsgrenzen beperkt is gebleven. De campagne startte in de jaren zeventig van de vorige eeuw, volgend op het strategische plan bedacht door Lewis Powell Jr., ${ }^{30}$ met een hoofdrol voor de US Chamber of Commerce (hierna: de Chamber). Meer historische details met verdere vindplaatsen over het ontstaan en de indrukwekkende ontwikkeling van

28. D. Engel, The myth of the litigious society. Why don't we sue more? (Chicago Series of Law and Society), Chicago, University of Chicago Press, 2016. Engel focust zich in zijn publicatie wel op een specifieke categorie gevallen: letselschade, en dat speelt zich af buiten het raamwerk van 'class actions'. Zie ook boekbesprekingen te raadplegen via: Kao, M. Bob (2017) Book review: the myth of the litigious society: why we don't sue by David M. Engel. LSE Review of Books (01 Feb 2017). Blog.

29. CJ\&D, Fact Sheet: Tort Litigation in the United States, 11 november 2011, te raadplegen via http://centerjd.org/content/fact-sheet-tortlitigation-united-states

30. Te raadplegen via: law2.wlu.edu/deptimages/Powell\%20Archives/ PowellMemorandumTypescript.pdf. deze machtige lobby zijn te vinden in het lezenswaardige artikel van Rathod en Vaheesan: ${ }^{31}$

'The confidential memo written for the Chamber of Commerce, entitled "Attack on the American Free Enterprise System," is a call to arms to American business. (...) To reshape public opinion Powell proposed a multipronged response by industry that would be led by the Chamber of Commerce. The plan of action focused on four fronts: media, education, politics and law (...). ${ }^{32}$

Powells plan leidde onder meer ertoe dat tussen 1968-1978 het aantal ondernemingen met 'PR offices' in Washington DC vermeerderde met een factor vijf en het aantal 'corporate political action committees' met een factor vier. Het aantal kantoren met geregistreerde lobbyisten steeg van 175 naar 2500, terwijl de Chamber haar budget tussen 1974-1980 zag verdrievoudigen. ${ }^{33}$ Een geheel nieuwe 'oorlogsindustrie' kwam tot stand, die haar bestaansrecht moest verdienen en handhaven. De overkoepelende en veelomvattende pr-strategie die Powell voorstelde, is in de opvolgende decennia consciëntieus en consequent geïmplementeerd onder de naam 'tort reform'campagne, met de bijbehorende communicatie-story line van 'business victimhood':

'This "tort reform" campaign deployed a common rhetorical mythology of business victimhood. Business victimhood was poll-tested and anchored in the ideas that: (1) businesses are victims of a litigation explosion and (2) litigation is an immoral and unjust method of dispute resolution. Businesses are victims, the narrative goes, of trial lawyers who play "jackpot justice" by drumming up frivolous litigation runaway juries who have never seen a damage award too large, and of Americans who file lawsuits for every injury no matter how small. According to the mythology, the result has been an overly litigious society that imposes massive burdens on American business and, by extension, American consumers and workers. ${ }^{34}$

In 1998 werd ook het Institute for Legal Reform (ILR) door de Chamber opgericht: het eigen onderzoeksinstituut dat Powells oorlogsplan een wetenschappelijke onderbouwing en uitstraling moest geven. ${ }^{35}$ Deze ontwikkelingen hebben de Chamber ook in de opvolgende decennia geen windeieren gelegd. Enkele cijfers ter illustratie, die afkomstig zijn van Open Secrets, Center for Responsive Politics: een ngo die zich profileert als 'the nation's premier research group tracking money in U.S. politics and effect on elections and public poli-

31. J. Rathod \& S. Vaheesan, The arc and architecture of private enforcement regimes in the United States and Europe: A view across the Atlantic, University of New Hampshire Law Review 2016, afl. 2, p. 303-374, ook te raadplegen via: scholars.unh.edu/cgi/viewcontent.cgi?article $=1252 \&$ context $=$ unh_lr.

32. Rathod \& Vaheesan 2016, p. 316-317.

33. Rathod \& Vaheesan 2016, p. 317-318 met verdere verwijzingen.

34. Rathod \& Vaheesan 2016, p. 318.

35. Zie www.instituteforlegalreform.com. 
cy. ${ }^{36}$ Open Secrets is een informatiebron die volgens kenners ${ }^{37}$ betrouwbaar en gezaghebbend is. Het verzamelt en publiceert openbare gegevens over geregistreerde lobbyactiviteiten. Het bevat daarmee informatie die indicatief is voor de activiteiten van de Chamber, haar financiële armslag, focus en aanpak. Het tabblad 'lobbyists' laat de geregistreerde lobbyisten zien, vaak verbonden aan grote Amerikaanse corporate advocatenkantoren. ${ }^{38}$ De tabbladen 'issues' en 'bills' laten de binnenlandse onderwerpen en wetsvoorstellen zien, waar de Chamber en haar lobbyisten in de afgelopen jaren aan gewerkt hebben. De onderwerpen, 'torts', 'law enforcement', 'fairness in class action litigation' en 'Arbitration Fairness Act' blijken tussen 2007-2017 verreweg de meeste lobbyaandacht te hebben gekregen. ${ }^{39}$ Achter de laatste twee aanduidingen schuilen lobbyactiviteiten die tot doel hebben om de toegang van benadeelden tot de overheidsrechter en/of 'class actions' in consumenten-, arbeids- en mededingingsgeschillen uit te sluiten of sterk aan banden te leggen ten gunste van gedwongen arbitrages, waarin geen collectieve afdoening mogelijk is. ${ }^{40}$

Het totaalbudget van de Chamber voor 2017 was ruim \$ 58 miljoen, waarvan ruim $\$ 15,5$ miljoen naar het eigen lobbyresearchinstituut (ILR) ging. ${ }^{41}$ De cijfers voor 2016 waren respectievelijk circa \$ 104 miljoen (totaal budget) en bijna \$28 miljoen ${ }^{42}$ voor ILR, voor 2015 circa \$ 85 miljoen en \$21,5 miljoen $^{43}$ (voor ILR) en voor $2014 \$ 124$ miljoen en ruim $\$ 33$ miljoen (voor ILR). ${ }^{44}$ De budgetten voor voorgaande jaren zijn eveneens beschikbaar en laten een soortgelijk financieel plaatje zien. Menig onafhankelijk universitair onderzoekscentrum kan daar alleen van dromen. Op de website van het ILR zijn onder 'issues' de onderwerpen te zien waarin geïnvesteerd is, onder andere: 'class actions', 'class actions around the globe', 'mass torts', 'third party funding', 'securities litigation reform', 'alien tort statute', enzovoort. Op dezelfde website zijn onder 'research' tevens studies te vinden die door het ILR gefinancierd zijn; de toonzetting is consistent in lijn met Powells battle plan en de communicatie-story line van 'business victimhood'.

36. Zie www.opensecrets.org/about/.

37. Met dank aan prof. D.R. Hensler.

38. Zie www.opensecrets.org/lobby/clientlbs.php?id=D000019798\&year= 2017. Namen van advocatenkantoren die daarop voorkomen, zijn o.a. Skadden Arps, Mayer Brown, Greenberg Traurig, King and Spalding, Morgan Lewis, Gibson Dunn, Debevoius \& Plimpton. Open Secrets bevat geen gegevens over de lobbyactiviteiten en de lobbyisten van de Chamber in het buitenland.

39. De gegevens kunnen per jaar worden ingezien: www.opensecrets.org/ lobby/clientbills.php?id=D000019798\&year $=2017$.

40. Voor een korte en instructieve beschouwing van de problematiek van de arbitration fairness act, zie www.arbresolutions.com/the-proposedarbitration-fairness-act-still-a-well-intended-but-potentially-dangerousoverreaction-to-a-legitimate-concern/.

41. Zie www.opensecrets.org/lobby/clientsum.php?id=D000019798\&year= 2017.

42. Zie www.opensecrets.org/lobby/clientsum.php?id=D000019798\&year= 2016.

43. Zie www.opensecrets.org/lobby/clientsum.php?id=D000019798\&year= 2015.

44. Zie www.opensecrets.org/lobby/clientsum.php?id=D000019798\&year= 2014.
Waarom is deze bespreking van de Chamber, haar historische ontwikkeling en haar lobbyactiviteiten in het kader van de 'tort reform'-campagne hier gepast? Het is algemeen bekend dat achter elke wetgeving lobbyorganisaties zitten, dat is immers niets bijzonders. Toch wel. Menige wetgevers, beleidsmakers en wetenschappers, media en het grote publiek zijn zich niet bewust van de kapitaalkracht en de grote macht, invloed en het bereik van deze lobby. Hoewel de Nederlandse wetgever het hoofd bij dit wetsvoorstel koel heeft gehouden en het bezigen van begrippen als 'claimcultuur', 'frivolous litigation' en 'black mail settlements' heeft geprobeerd te vermijden, dient hij rekening te houden met de Chamber en haar Europese lobbyisten ${ }^{45}$ en met het anti-'US style litigation'-sentiment op Europese bodem. De Chamber, Powells plan en gerelateerde story line van 'business victimhood' implementerend, is geslaagd in het aanwakkeren en handhaven van een angstcultuur ${ }^{46}$ voor 'litigation explosion', 'frivolous law suits' en 'black mail settlements' tegen weerloze en onschuldige gedaagden. Dat is de context waarin het pakket aan belemmeringen in het wetsvoorstel, dat door verschillende collega's reeds gesignaleerd is, ${ }^{47}$ moet worden gelezen. Belemmeringen waarvoor de noodzaak weliswaar niet steeds 'evidence based' is, ${ }^{48}$ maar die mede beïnvloed worden door de 'tort reform'campagne van de Chamber in Europa: ${ }^{49}$

'The European Commission has embraced a narrative on the American tort system that is fundamentally false. This story of excess is not based on empirical fact. Rather, it relies almost exclusively on distorted anecdotes and misrepresentations of recent history. (...) The "exporting" of the U.S. tort reform story to the European Union is unfortunate for European consumers and small businesses. ${ }^{50}$

De stigmatisering van 'class actions' en privaatrechtelijke rechtshandhaving komt niet voor in andere jurisdicties met ruime 'class actions'-ervaring, zoals Canada en Australië. Daar is het uitgangspunt bij beleidsmakers, binnen de rechterlijke macht en het grote publiek juist dat collectieve acties de toegang tot het recht vergroten en niet goed van de grond kunnen komen zonder commercieel opererende partijen en adequate financiële incentives. ${ }^{51}$ Ook belangenbehartigers van gedaag-

45. Meer informatie hierover is te vinden op: lobbyfacts.eu/representative/ 605251a3bc794bc489fc05301de36b1e/american-chamber-of-commerce-to-the-european-union. Niet alle lobbyactiviteiten worden echter geregistreerd.

46. Hensler 2014 bespreekt een voorbeeld op het terrein van 'third party funding'.

47. O.a. Bauw \& Voet 2017 en Van Boom \& Weber 2017.

48. Zie over dit probleem in de Nederlandse wetgevingscontext recent ook Vermolen \& Van Boom 2017

49. Zie het ILR, dat zich heel specifiek op 'class actions'-ontwikkelingen richt buiten de VS, onder meer Canada en Europa: www. instituteforlegalreform.com/issues/class-actions-around-the-globe; zie voorts Hensler 2014, voetnoot 4.

50. Rathod \& Vaheesan 2016, p. 355.

51. Voor Australië, zie bijv. Campbell's Cash \& Carry Pty Ltd v. Fostif Pty Ltd [2006] HCA 41, voor Canada: Fantl v. Transamerica Life Canada, 2009 ONCA 377, par. 67 en McCracken v. Canadian National Railway Company, 2010 ONSC 6026, par. 11. 
den bevestigen het beeld dat 'class actions' nuttig zijn en tot behavior modification leiden. ${ }^{52} \mathrm{Er}$ wordt vervolgens naar gekeken hoe commerciële prikkels in het civiele proces in goede banen kunnen worden geleid om excessen te voorkomen, maar dat een uitsluitend ideële instelling ontoereikend is om effectief te zijn en dat entrepreneurial lawyering ook aan de eisende kant nodig is en niet gemist kan worden, staat in die rechtsstelsels buiten kijf en wordt geaccepteerd en gefaciliteerd. In Nederland en Europa is commercie aan de eisende kant in het kader van collectieve acties nog altijd uit den boze: ${ }^{53}$ de Claimcode en de Europese Aanbeveling zijn exponenten van deze denkwijze en laten een zekere innerlijke tegenstrijdigheid zien. Aan belangenorganisaties worden eisen gesteld die de aanwezigheid van deep pockets noodzakelijk maken, maar de toegang van die organisaties tot deep pockets wordt op allerlei manieren aan banden gelegd, zonder dat reële alternatieven worden aangereikt: dé manier om collectieve acties buiten spel te zetten. Aan het commerciële aspect aan de zijde van verweerders in het kader van collectieve acties wordt doorgaans geen aandacht geschonken. Vermeldenswaard is daarom de observatie van prof. Halfmeier naar aanleiding van de Deutsche Telecom-zaak over de kosten van verweerders in de VS 'class action'. De kwestie betrof beleggingsschade, vergelijkbaar met de Nederlandse World Online-zaak:

'With respect to the economics of the legal profession, it is interesting to note that the defence lawyers' non-contingent fees amount to about 18 percent of the settlement value, in relation to 28 percent on the plaintiffs' side as a fully contingent fee'. ${ }^{54}$

Vermeldenswaard is voorts dat terwijl de Amerikaanse beleggers in deze zaak al tien jaar geleden hun schadevergoeding ontvingen, de Duitse beleggers in dezelfde feitelijke kwestie nog steeds aan het procederen zijn en voor hen is nog steeds geen resultaat bereikt. Als meer discussie, openheid en transparantie over de financiële prikkels, verdienmodellen en commerciële aspecten ook aan de verwerende kant in 'class actions' zou komen, zou dat een totaalbeeld geven en de bezwaren tegen de kosten en baten van 'class actions' in perspectief en context plaatsen. Dat zou tevens bijdragen aan een evenwichtigere beeldvorming.

De wetgever stelt zich in de financieringsdiscussie neutraal op, door enerzijds de Claimcode te codificeren en anderzijds het belang van adequate financiering voor collectieve acties te onderkennen en de mogelijke aanwezigheid van externe com-

52. Aldus prof. J. Kalajdzic die in opdracht van de Ontario Law Commission een Canadees kwalitatief empirisch onderzoek naar het onderwerp leidt. Dat zal resulteren in aanbevelingen en/of een publicatie.

53. Er zijn ook relativerende stemmen: K. Rutten, Art. 3:305a lid 2 BW schiet zijn doel voorbij!, MvV 2015, afl. 11, p. 324.

54. A. Halfmeier, Litigation without end? The Deutsche Telekom case and the German approach to private enforcement of securities litigation, in: D.R. Hensler, Ch. Hodges \& I.N. Tzankova (red.), Class actions in context, Cheltenham UK, Edward Elgar Publishing 2016, p. 286, voetnoot 11. merciële financiering aan de eisende kant in collectieve acties als een gegeven aan te nemen. Maar is een neutrale opstelling voldoende om de voorgestelde collectieve actie daadwerkelijk effectief te laten zijn?

\section{De economische realiteit van massaschade}

Als collectieve acties de motor zijn van privaatrechtelijke handhaving, ${ }^{55}$ dan is toereikende en adequate financiering het elektrische oplaadpunt daarvoor. En zonder stroom komen elektrische auto's niet ver. Hierna sta ik stil bij de vraag of wij in Nederland voldoende van de spreekwoordelijke oplaadpunten hebben om collectieve acties adequaat te voeren en/of het wetsvoorstel dit aspect in voldoende mate adresseert. Daarnaast sta ik kort stil bij de financiering van verweerders.

\subsection{Wat kost een collectieve actie?}

Het voeren van collectieve acties is kostbaar, zeker sinds de Claimcode. ${ }^{56} \mathrm{Nu}$ deze in het wetsvoorstel wordt gecodificeerd om het governanceprobleem van ad-hocclaimstichtingen die 3:305a-acties instellen te adresseren, is het goed om uitgebreider stil te staan bij wat de praktische implicaties hiervan zijn. ${ }^{57}$ Over wat voor kosten hebben we het? Denk behalve aan de initiële notariële oprichtingskosten, ook aan de kosten van drie deskundige, professionele, ervaren, onafhankelijke en niet-commerciële bestuursleden en aan de leden van de raad van toezicht, eveneens het liefst drie deskundige, professionele, ervaren, onafhankelijke en niet-commerciële personen. Hier komen nog bij de kosten van een bestuurdersaansprakelijkheidsverzekering. Aangenomen dat de stichting al bestuursleden vindt die aan de criteria voldoen, beschikbaar zijn en bereid om zitting te nemen in het bestuur van een claimstichting, zullen ze daar doorgaans de voorwaarde van een adequate bestuurdersaansprakelijkheidsverzekering aan verbinden, of ten minste een vrijwaring tegen eventuele claims verlangen. Daar kunnen behoorlijke kosten aan verbonden zijn, zeker als de belangen groot zijn, en dat is bij massaschade snel het geval. ${ }^{58}$ Daarnaast is de laatste tijd een trend waarneembaar om voor dergelijke verzekeringspolissen naar Lloyds Londen uit te wijken, omdat de Nederlandse verzekeringsmarkt het aanbieden van dit product niet (langer) kan of wil faciliteren. De rekening voor belangenorganisaties wordt daardoor steeds hoger. Dan zijn er nog de kosten van het onderhouden en bij-

55. Tzankova 2005, p. 49-69 en 130-132, over het belang van privaatrechtelijke handhaving via collectieve afwikkeling.

56. De Claimcode is alleen van toepassing op entiteiten die 3:305a-collectieve acties voeren, en niet op zogenoemde special purpose vehicles, die uitsluitend via overeenkomsten van cessie en lastgeving optreden; zie de considerans bij de Claimcode: www.consumentenbond.nl/binaries/ content/assets/cbhippowebsite/bestanden-oud/pdf-algemeen-2013/ compljuniclaimcodecomm2011.pdf.

57. Het is wel zo dat de Claimcode het 'comply or explain'-principe hanteert en dat de code thans geëvalueerd wordt, maar voor het wetsvoorstel komt deze evaluatie te laat en de procesdynamiek is inmiddels zodanig dat het de belangenorganisaties die een goede reden hebben om de Claimcode niet te volgen in de verdachtenbank plaatst, hetgeen tot extra juridische schermutselingen leidt.

58. Een 'bescheiden' D\&O-verzekering kost op jaarbasis al snel $€ 5.000$. Afhankelijk van de dekkingsomvang en of het een internationale kwestie betreft, kan de premie op jaarbasis het veelvoudige hiervan bedragen. 
houden van een website, van externe en interne communicatie (de achterban moet op de hoogte worden gehouden, de media moeten te woord worden gestaan), de bankrekening, ledenwerving en dossieronderzoek en -vorming; wij willen immers dat stichtingen een achterban hebben, bestaande uit de doelgroep die met het probleem in kwestie te maken heeft en niet alleen een mening heeft over de kwestie. Verder zijn er de kosten van de accountant die de financiële administratie jaarlijks moet controleren, en de overige administratie- en coördinatiekosten van dit alles. Enkele honderdduizenden euro's zijn reeds aan het begin nodig, voordat ook maar een brief richting de wederpartij is gegaan. De professionalisering van claimstichtingen 'comes at a price', kwaliteit en verbetering van governance ook.

De kosten van de advocaat of advocaten van de stichting, de expert(s), de griffiekosten en/of het eventuele risico van een proceskostenveroordeling in drie of zelfs meer instanties, soms tegen meerdere gedaagden, komen daar nog bovenop. Omdat de eiser in collectieve acties geacht wordt mede ten behoeve van anderen op te treden, maar het procesrisico en de kosten niet met de groepsleden kan delen, zelfs niet in geval van succes, vormt dat een extra belemmering voor het initiëren van collectieve acties.

Systematisch empirisch onderzoek naar de kosten van collectieve acties in Nederland ontbreekt, maar er zijn wel enige gegevens voorhanden, waaruit een indicatie en een 'educated guess' en/of een extrapolatie kunnen volgen. Zo gaven de verschillende belangenorganisatie die betrokken zijn bij de collectieve Fortis-schikking ${ }^{59}$ desgevraagd aan het Hof Amsterdam te kennen dat de kosten voor acht jaar procederen per organisatie tussen $€ 2,5$ en 7 miljoen bedroegen. Het ging om vier organisaties, waarvan niet alle aan de Claimcode voldeden, in dat geval waren hun kosten mogelijk nog hoger geweest. De optelsom van de organisatie- en proceskosten van alle vier resulteert in een bedrag van enkele tientallen miljoenen euro's. Hier komen nog bij de schikkings- en afwikkelingskosten en de administratiekosten van de schikking, mocht deze verbindend worden verklaard. Dit beeld lijkt niet irreëel: bij de DSBschikking was ook sprake van vier belangenorganisaties en daar was een kleine $€ 4$ miljoen gemoeid met vergoedingen aan die organisaties, alleen al tijdens de onderhandelingen en voor de uitvoering van de regeling. ${ }^{60}$ De advocaatkosten van de Stichting Vie d'Or voor ruim tien jaar procederen bedroegen circa $€ 2$ miljoen. De kosten van het professioneel opgezette secretariaat van de stichting gedurende al die jaren, de onkostenvergoeding van de bestuursleden ${ }^{61}$ en overige schikkingskosten komen daar nog bovenop. Op basis van het bovenstaande lijkt een veilige aanname dat het langdurig collectief

59. Hof Amsterdam 16 juni 2017, ECLI:NL:GHAMS:2017:2257, r.o. 8.34, OR-Updates.nl 2017-0191, NTHR 2017, afl. 5, p. 302.

60. 32ste Openbaar Verslag van de curatoren van DSB Bank van 29 juli 2016, p. 9 (zie www.dsbbank.nl). Let op dat het hier alleen om de kosten van schikken ging en niet van procederen en van zowel de organisaties zelf als hun belangenbehartigers.

61. In die tijd nog op pro-bonobasis, dat is niet langer de maatstaf. procederen over een complex onderwerp dat tot een schadevergoeding zou moeten leiden voor één groep benadeelden al snel tussen $€ 3$ en 7 miljoen kost en meer indien de Claimcode strikt wordt gevolgd en langer dan vijf tot zeven jaar geprocedeerd wordt. Laten we nu bekijken wat de huidige financieringsopties voor eisers in Nederland zijn om aan dit bedrag te komen.

\subsection{De huidige financieringsopties voor eisers op een rij} Juristen zijn alfa's en hebben doorgaans een moeizame relatie met cijfers. Een korte toelichting op de huidige financieringsopties voor collectieve acties en hun voor- en nadelen is echter essentieel voor een goed begrip van de massaschadeafwikkeling. ${ }^{62}$ Aangenomen dat een complexe en degelijk opgezette collectieve schadevergoedingsactie in Nederland al snel tussen $€ 3$ en 7 miljoen kost, welke opties bestaan er dan om de financiering hiervoor rond te krijgen? Een nadere analyse van de thans beschikbare mogelijkheden leidt tot weinig bemoedigende bevindingen. ${ }^{63}$ De Dexia-zaak werd de gefinancierde rechtsbijstand bijna fataal; de kwestie trok veel eenpitters aan, zonder specialistische kennis. Tegelijkertijd ontbeerde het de gefinancierde rechtsbijstand aan mogelijkheden om de zaken te stroomlijnen, vanwege het recht op een advocaat naar eigen keuze. Een oplossing zou kunnen zijn om 3:305a-belangenorganisaties als ontvangers van gefinancierde rechtsbijstand te kwalificeren, maar de vraag is of men zou moeten willen dat de van overheidswege gefinancierde rechtsbijstand de structurele oplossing voor de financiering van consumentenmassaschade in Nederland wordt. Bovendien zijn er veel gevallen van massaschade die geen consumenten betreffen. Algemeen-belangacties zouden wel een uitzondering kunnen vormen, maar daar vallen de collectieve schadevergoedingsacties vaak niet onder. Bovendien kunnen openbare middelen wellicht beter aan het strafrecht worden besteed, waar het aantrekken van alternatieven voor kwalitatief hoogwaardige rechtsbijstand lastiger is. Deze optie valt sowieso af. Op naar de volgende. 'Full contingency fees' ${ }^{64}$ zijn vooralsnog niet toegestaan volgens de Nederlandse Orde van Advocaten, ${ }^{65}$ dus deze optie, die vooral in de VS, Canada, Israël, Spanje en (zelfs) Zweden bij collectieve acties wordt aangewend, is hier niet aan de orde.

Ook het volgende alternatief: het verlangen van een eigen bijdrage van gedupeerden, is evenmin een makkelijke en/of structurele oplossing gebleken. $\mathrm{Zij}$ is afhankelijk van de grootte van de groep en de betalingsdiscipline en bereidheid van groepsleden om bij te dragen aan de actie. Een belangenorganisatie zal een behoorlijke inspanning moeten leveren - met een onzekere uitkomst - om voldoende benadeelden aan zich te binden die tijdig de eigen bijdrage willen betalen, om aan de

62. Zie ook C. Cameron, J. Kalajdzic \& A. Klement, Economic enablers, in: Hensler, Hodges \& Tzankova 2016, p. 137-169.

63. I.N. Tzankova, Funding of mass disputes: Lessons from the Netherlands, Journal of Law, Economics and Policy (8) 2014, afl. 3, p. 549-591 met verdere verwijzingen. De informatie in deze paragraaf is daaraan ontleend.

64. In de volksmond 'no cure, no pay'.

65. Met uitzondering van individuele letselschadezaken. 
ondergrens van $€ 3$ tot 7 miljoen te komen. Dat zal niet makkelijk gaan: de Nederlandse consument weet inmiddels ook dat freeriden op de inspanningen van anderen een 'consumentenrecht' is. ${ }^{66}$ De ervaringen met de Stichting Loterijverlies laten bovendien zien waarom deze methode ook om andere redenen problematisch kan zijn: daar was een behoorlijke oorlogskas redelijk snel gevuld en ook nog gecombineerd met een 'contingency fee' gerelateerd aan een percentage van de uitkomst, maar de initiator liep zelf geen financieel risico en had onvoldoende incentives om tot een tastbare oplossing voor de achterban te komen. Ook deze optie brengt ons niet ver.

Doordat steeds meer personen en entiteiten over een rechtsbijstandsverzekering beschikken, zou dat wellicht een meer structurele benadering van de financieringsvraag kunnen zijn, maar ook daar treft men de nodige beperkingen aan: de polisdekking en -voorwaarden zijn in geval van massaschade vaak zodanig beperkt en bovendien versnipperd, dat het treffen van een adequate financieringsregeling met rechtsbijstandsverzekeraars lastig is. ${ }^{67}$ Een verzekerde krijgt in gevallen van massaschade doorgaans de dekking uitgekeerd naar rato van zijn aandeel in de groep. Dat is een maatregel die beoogt het freeriderprobleem bij rechtsbijstandsverzekeraars te adresseren en het verdienmodel van de verzekeraars zeker te stellen: de premie heeft geen rekening gehouden met de kosten van een eventuele collectieve actie. Bijvoorbeeld: als in een dossier sprake is van in totaal 500.000 benadeelden, zal in beginsel per verzekerde $1 / 500.000$ van de juridische kosten onder de, doorgaans ook in financieel opzicht beperkte, polisdekking worden uitgekeerd. Dat veronderstelt niet alleen wetenschap over de omvang van de groep, maar vereist ook medewerking en identificatie van alle groepsleden met een rechtsbijstandverzekering en hun bereidheid tot samenwerking. Bereidheid tot samenwerking door hun verzekeraars zou onvoldoende zijn en overigens problematisch, omdat het tot een verstoring van de mededinging zou kunnen leiden. Het is de verzekerde en niet de verzekeraar die tot de samenwerking in geval van massaschade bereid moet zijn en het nut en de noodzaak daarvan moet inzien. Dat zal in de regel niet het geval zijn zonder adequate informatie en voorlichting. Ook daar blijft de keuze van de eigen advocaat een extra complicerende factor, terwijl de advocaten van verzekeraars zelf lang niet altijd over de in sommige dossiers nodige specialistische kennis beschikken. Een speciale 'before-or-after-the-event' rechtsbijstandverzekering

66. Hof Amsterdam 16 juni 2017, ECLI:NL:GHAMS:2017:2257, r.o. 8.22-24, OR-Updates.nl 2017-0191, NTHR 2017, afl. 5, p. 302. W.H. van Boom \& C.M.D.S. Pavillon, Meer kans in de staatsloterii? (HR 30 januari 2015, ECLI:NL:HR:2015:178, Stichting Exploitatie Nederlandse Staatsloterij/Stichting Loterijverlies.nl), AA 2015, p. 784-793. Voor een kritische bespreking van dit 'consumentenrecht', zie Tzankova 2015.

67. Zie meer in het algemeen over het businessmodel van rechtsbijstandsverzekeraars en de bijbehorende agency problematiek W.H. van Boom, Financing civil litigation by the European insurance industry, in: M. Tuil \& L. Visscher, New trends in financing civil litigation in Europe: A legal, empirical, and economic analysis, Cheltenham UK, Edward Elgar Publishing 2010, p. 92-109 en Tzankova 2014 in verband met hoe dat business model zich tot de financiering van massaschade verhoudt. in geval van massaschade zou wellicht voor de toekomst een idee zijn, maar vooralsnog is die er niet. Hoewel in theorie antrekkelijk, is ook deze optie in de praktijk van massaschade een lastige gebleken. Een speciaal van overheidswege in het leven geroepen Fonds Collectieve Acties, zoals in Canada en Israël, kent Nederland evenmin, waarbij aantekening verdient dat in Canada 'full contingency fees' zijn toegestaan en het Ontario-fonds alleen expertisekosten en het risico van een proceskostenveroordeling dekt. Het fonds is na een beperkte initiële storting door de overheid overigens zelfvoorzienend geworden. ${ }^{68}$ De advocaten worden nog steeds geacht om hun eigen kosten te dragen en hun 'success fee' voor het gelopen risico met het fonds te delen (10\% gaat naar het fonds). De Nederlandse opties beginnen uitgeput te raken. Banken verlenen geen lening voor het voeren van procedures, en als ze dat al zouden doen, zullen ze het geleende bedrag vermeerderd met rente na de afgesproken periode altijd terugbetaald willen zien, ook als de actie niet succesvol is. Het is niet aan te bevelen om geld bij vrienden en familie te lenen, aangenomen dat dezen daarover beschikken en een lening zien zitten. Het enige alternatief dat nog overblijft, afgezien van niets ondernemen, is het proberen om een externe financiering aan te trekken bij een commerciële partij, tegen gangbare commerciële voorwaarden. Echter: dit is een relatief nieuw fenomeen, ${ }^{69}$ dat is overgewaaid uit Australië, waar 'contingency fees' voor advocaten ook verboden zijn, en 'third party funding' ofwel procesfinanciering heet. Over de formele definitie van deze term bestaat internationaal gezien nog geen overeenstemming, maar dit is alvast de definitiepoging van een werkgroep van de ICCA: ${ }^{70,71}$

'The term "third-party funder" refers to any natural or legal person who is not a party to the dispute but who enters into an agreement either with a disputing party, an affiliate of that party, or a law firm representing that party:

a. in order to provide material support or to finance part or all of the cost of the proceedings, either individually or as part of a selected range of cases, and

b. such support or financing is provided either through a donation or grant or in return for remuneration or reimbursement wholly or partially dependent on the outcome of the dispute.'

Van Boom ${ }^{72}$ definieert procesfinanciering als:

68. Cameron, Kalajdzic \& Klement 2016 en Tzankova 2015

69. Zie voor een bespreking hiervan in de Nederlandse context J.J. Dammingh \& L.M. van den Berg, Procesfinanciering door derden: een oplossing of een probleem? Verslag van de najaarsvergadering 2016 van de Nederlandse Vereniging voor Procesrecht, TCR 2017, afl. 2, p. 78-82 en W.H. van Boom \& J.L. Luiten, Procesfinanciering door derden, RMThemis 2015, afl. 5, p. 188-199.

70. ICCA staat voor International Council for Commercial Arbitration.

71. Van de ICCA-Queen Mary Task Force on Third-Party Funding in International Arbitration: www.arbitration-icca.org/news/2017/350/thirdparty-funding-draft-report-now-available-online-for-public-comment. html.

72. Zie willemvanboom.blog/category/consumentenrecht/. 
'een overeenkomst waarbij een persoon, de claimant, die meent een vorderingsrecht tot betaling van een geldsom of schadevergoeding te hebben op een wanpresterende wederpartij of laedens, belooft om een deel van de uiteindelijke opbrengst van de vordering (na rechterlijke toewijzing of schikking en incasso) af te staan aan een derde die geen bestaande betrokkenheid heeft bij de zaak, de procesfinancier, in ruil waarvoor deze derde de kosten van advocaten, deskundigen, griffierechten en mogelijk ook de proceskostenveroordeling ingeval van verlies van de procedure op zich neemt. Deze derden zijn veelal professionele, internationaal opererende investeringsmaatschappijen of aan verzekeringsindustrie gelieerde financieringsmaatschappijen. De overeenkomst heeft dus trekken van no cure no pay (resultaatafhankelijke beloning) en contingency fee (beloning in de vorm van een percentage van de opbrengst van de vordering; ook wel quota pars litis genaamd).'

Van belang is dat de financieringsfaciliteit door de procesfinancier of 'third party funder' (TPF) verstrekt wordt op zogenoemde 'non-recourse'-basis. Dat wil zeggen dat deze, anders dan bij een banklening, alleen terugbetaald hoeft te worden in geval van succes. Als er geen succes wordt behaald, absorbeert de procesfinancier alle kosten van de procedure en hoeft de client de faciliteit niet terug te betalen. Dat verklaart waarom procesfinanciers uiterst kritisch zijn bij de selectie van de zaken die zij financieren en waarom zij een succesopslag hanteren die veel hoger is dan de gebruikelijke rente op bankleningen op dat moment. Een banklening is gestoeld op de gedachte dat deze na een vooraf afgesproken periode wordt terugbetaald, waarvoor ook nog zekerheden worden bedongen. Omdat bij procesfinanciering alleen in geval van succes een terugbetalingsverplichting bestaat en het onzeker is of en wanneer dat gerealiseerd wordt, wordt een hogere risico-opslag overeengekomen dan bij een banklening het geval zou zijn. De risico-opslag in het kader van procesfinanciering kan, mede afhankelijk van procesrisico en schadeomvang, al snel tussen 20 en $40 \%$ van de uitkomst van de procedure zijn al dan niet gecombineerd met een multiplier van de investering, in een enkel geval hoger, zelden lager. ${ }^{73}$ Alleen terugbetalen van de faciliteit volstaat dus niet. Geen enkele commerciële partij, ook een bank niet, zou met een dergelijke afspraak akkoord gaan, en zelfs het Ontario-fonds, dat een non-profitkarakter heeft, rekent een standaardopslag van $10 \%$ van het resultaat, die boven op de 'success fee' komt die aan de advocaat die op 'full contingency fee'-basis optreedt, wordt betaald. Tot slot verdient vermelding dat bestaande belangenorganisaties soms ook als 'procesfinanciers' fungeren, waarvan de VEB en de Consumentenbond de bekendste voorbeelden zijn. Echter: ook hun mogelijkheden zijn beperkt en zij moeten zich in collectieve acties ook steeds commerciëler gaan gedragen om de hoge kosten van collectieve acties op te kunnen brengen en het freeriderprobleem te adresseren. De eerdergenoemde collectie-

73. Voor een insidersblik in de factoren die de uiteindelijke prijsvorming van een TPF bepalen zie: N. Rowles-Davies, Third party litigation funding, Oxford, Oxford University Press 2014, p. 117-119. ve Fortis-schikking, waarin de door VEB opgeëiste vergoeding van $€ 25$ miljoen voor veel beroering zorgde, illustreert deze nieuwe ontwikkeling. Het laat ook zien waarom het al dan niet non-profitkarakter van een belangenorganisatie geen adequaat criterium is in het kader van de beoordeling van de ontvankelijkheid van collectieve schadevergoedingsinitiatieven: daar hebben commerciële (Deminor), ad-hocbelangenorganisaties met commerciële financiering (FortisEffect en Sicaf) en non-profitbelangenorganisaties (VEB) met een commerciële geest een oplossing bereikt. De helft van de organisaties voldoet niet aan de Claimcode, maar daar lijkt het hof weinig waarde aan te hechten. Bestaande non-profitbelangenorganisaties kennen bovendien een eigen agencyproblematiek die ik volledigheidshalve aanstip, maar hier verder buiten beschouwing laat. Daar is meer onderzoek naar wenselijk. ${ }^{74}$

De uitkomst van de analyse naar de bestaande financieringsopties aan de eisende kant in geval van massaschade is dat er in Nederland onvoldoende 'oplaadpalen' zijn om collectieve acties in overeenstemming met de Claimcode te voeren. Bij gebrek aan werkbare alternatieven moet het huidige systeem het vooral van commerciële procesfinanciering hebben. Deze is naar haar aard kostbaar en bovendien niet eenvoudig verkrijgbaar. De vraag is echter of het wetsvoorstel ervaren en professionele ${ }^{75}$ procesfinanciers voldoende waarborgen biedt om een Nederlandse collectieve actie te willen financieren. Deze vraag valt naar mijn mening niet zonder meer positief te beantwoorden. Ik leg hierna uit waarom, nadat ik de financiering aan de zijde van verweerders in geval van massaschade kort behandel.

\subsection{De financiering van verweerders in geval van massaschade}

Zoals werd aangestipt in paragraaf 2.3 is over de financiering van verweerders in geval van massaschade weinig bekend, behalve dat de dynamiek van massaschade ervoor zorgt dat het voor verweerders meer loont om veel in het verweer te investeren, dan dat het voor een individuele schadelijder loont om in de onderbouwing van de claim veel middelen te steken. Daardoor is er sprake van een inherente asymmetrie in de investeringsincentives bij veroorzakers van massaschade en bij individuele benadeelden. Alleen door een organisatie van een groep aan de eisende kant komen de financiële incentives om te investeren in kwalitatief hoogwaardige rechtsbijstand aan bei-

74. Meer over deze problematiek is te vinden bij A. Barroilhet, Self-interested gatekeeping? Clashes between public and private enforcers in two Chilean class actions, in: Hensler, Hodges \& Tzankova 2016, p. 362-386 en B. Stier \& I.N. Tzankova, The culture of collective litigation: A comparative analyses, in Hensler, Hodges \& Tzankova 2016, p. 36-40 (39): 'What the case studies demonstrate is that agency problems do not disappear when we eliminate private enterpreneurial laywers from class litigation and that public entities, long-standing associations or ad hoc approved antities each present their own agency problems, although perheps of a different sort.'

75. Met ervaren en professionele third party funders doel ik op partijen die voldoende gekapitaliseerd zijn en een adequaat trackrecord hebben. 
de kanten weer in balans. ${ }^{76}$ Dat verklaart deels waarom verweerders in gevallen van massaschade steeds hoogwaardige en kostbare expertise aantrekken. De aanwezigheid van incentives om te investeren zegt echter niets over de daadwerkelijke mogelijkheden om kostbare investeringen te doen. Doordat verweerders in de regel economische en op het genereren van winst gerichte entiteiten zijn, zullen zij doorgaans over meer middelen beschikken dan non-profitinstellingen om collectieve procedures te voeren en hoogwaardige expertise aan te trekken. Dat is een tweede inherente financieringsasymmetrie tussen eisers en gedaagden in gevallen van massaschade in het huidige en het voorgestelde Nederlandse systeem. Vaak zijn verweerders bovendien verzekerd voor de kosten van rechtsbijstand voor schade als gevolg van hun economische activiteit en voor de schade als gevolg van die activiteit. Dat zal hun financiële mogelijkheden van verweer verruimen, hoewel de dekking ook daar beperkt zal zijn. Tot slot vermeld ik een zeer recente trend, waarbij TPF ook voor verweerders beschikbaar is in het kader van een zogenoemde 'corporate portfolio financing, ${ }^{77}$ maar over deze nieuwe ontwikkeling en haar implicatie voor collectieve acties is nog minder bekend. Terug naar TPF aan de eisende kant.

\subsection{Freeriders en aanverwante perikelen}

Het wetsvoorstel introduceert de zogenoemde 'one way cost shifting rule', die inhoudt dat een belangenorganisatie alleen in het geval van succes van de actie, aanspraak kan maken op vergoeding van de reële proceskosten. ${ }^{78}$ De regel geldt alleen voor de belangenorganisatie en niet als de verweerder de procedure wint. Dat is op zichzelf genomen een maatregel die zou kunnen bijdragen aan de verbetering van de positie van belangenorganisaties met legitieme claims, maar het is onvoldoende. Onduidelijk is of onder de reële proceskosten ook de risicoopslag van een commerciële financier wordt begrepen. Vermoedelijk niet. In dat geval zal het niet eenvoudig, zo niet onmogelijk zijn om een kapitaalkrachtige partij te vinden die bereid zal zijn om jarenlang de hoge kosten en het risico van collectief procederen te dragen, zonder daarvoor behoorlijk beloond te willen worden. Ik legde in de vorige paragraaf reeds uit waarom het enkel terugbetalen van de financieringsfaciliteit, zonder een passende risico-opslag, geen procesfinancier zal aantrekken. Aannemende dat de risico-opslag van de TPF in geval van succes niet van de wederpartij kan worden geclaimd, zal die moeten worden betaald door de belangenorganisatie en de bij haar angesloten partijen. Dat levert echter een nieuw probleem op, dat van de freeriders.

Anders dan sommige critici kan ik de wetgever goed volgen in zijn keuze voor een stroomlijning van de belangenbehartiging en voor de invoering van de figuur van de ebb, in die zin dat uit een aantal gegadigden de meest geschikte(n) word(t)(en) gekozen. In combinatie met een opt-outregime leidt dat in

76. I.N. Tzankova, Toegang tot het recht bij massaschade (diss Tilburg), 2007, hfdst. 2 met verdere verwijzingen.

77. Rawles-Davies 2014, p. 74-75.

78. Art. $10181 \mathrm{Rv}$ theorie tot een regeling die het aanbrengen van collectieve acties maximaal zou moeten faciliteren. Dat is de theorie. In de praktijk zal het niet zo zijn, omdat de voorgestelde regeling in feite een opt-inregeling is: het vergt het actief bijeenbrengen van een achterban van benadeelden om representativiteit aan te tonen. Zeker als er meerdere concurrerende belangenorganisaties te verwachten zijn. Het vergt actieve maatregelen en daarmee gepaard gaande financiering om zo veel mogelijk steun en benadeelden contractueel aan zich te binden, terwijl de niet contractueel gebonden meerderheid passief afwacht, en dat ook mag doen door het opt-outkarakter van de actie in het wetsvoorstel. De meerderheid zal de neiging hebben om af te wachten. De combinatie van deze twee - enerzijds de noodzaak van het verzamelen van een achterban om representativiteit aan te tonen en anderzijds de afwezigheid van een prikkel bij de achterban om actief te worden - plaatst de belangenorganisatie en haar financier in een lastige situatie. Immers, de financier zal een commercieel redelijke 'success fee' en/of risico-opslag willen bedingen, die gebaseerd is op een percentage van de uitkomst, een multiplier van de investering of een combinatie van deze twee. Dat betreft een contractuele afspraak met de belangenorganisatie en de bij haar aangesloten partijen. Voordat het voor de financier aantrekkelijk wordt om een collectieve actie te financieren, zal de belangenorganisatie een voldoende grote achterban contractueel aan zich moeten weten te binden, die daadwerkelijk schade heeft geleden. Dat is naar mijn mening ook de reden waarom bestaande belangenorganisaties, zoals de VEB en de Consumentenbond, niet noodzakelijkerwijs een betere positie hebben dan ad-hocorganisaties in het wetsvoorstel. Ook zij zullen naar mijn mening moeten aantonen dat zij een achterban hebben die door de desbetreffende kwestie is geraakt. ${ }^{79}$ Het voldoen daaraan is logistiek en organisatorisch gezien problematisch en arbeidsintensief, ook voor bestaande belangenorganisaties. Wel hebben bestaande belangenorganisaties het voordeel dat zij over een basisledenbestand beschikken, waaruit zij zouden kunnen putten om benadeelden in een concreet geval aan zich te binden. Doordat freeriders of niet-actieve groepsleden niet hoeven bij te dragen in de kosten van de procedure, omdat zij geen contractueel overeengekomen 'success fee' hoeven te betalen, worden zij in feite voordeliger behandeld dan de actieve groepsleden, die in geval van succes altijd een deel van hun vergoeding aan de financier of de organisatie zullen moeten afstaan. Dat is niet te rechtvaardigen en demotiverend voor de actieve groepsleden. Er zullen uiteindelijk steeds minder actieve belanghebbenden worden gevonden om zich aan te melden en de kar voor de groep te trekken, en het zal daardoor steeds lastiger worden

\footnotetext{
79. Anders zou zich de situatie kunnen voordoen dat een bestaande organisatie die over veel leden beschikt die niet of nauwelijks met het concrete probleem, waarvoor schadevergoeding wordt gevraagd, te maken hebben, een stem zouden krijgen ten koste van een ad-hocorganisatie die in absolute getallen wellicht over minder leden beschikt, maar in relatieve zin over meer, omdat de leden die zich hebben aangesloten wel allemaal benadeeld zijn. Het vereiste van representativiteit brengt m.i. mee en laat zien waarom collectieve acties voor schadevergoeding inderdaad van een ander soort zijn dan die waarin gebod of verbod wordt gevraagd. De ont-
} vankelijkheidseisen horen daar onderscheid in te maken. 
om externe commerciële financiering aan te trekken. Terwijl verweerders de voordelen hebben van het opt-outregime en de finaliteit daarvan, hebben de belangenorganisaties en hun financiers in feite nog steeds met een opt-insysteem en dito kosten te maken, alsmede de onzekerheid of het hun gaat lukken om een voldoende omvangrijke achterban te verzamelen. Ondertussen moeten ze de aanzienlijke kosten van bestuur, ledenwerving en dossieronderzoek door advocaten en experts voorfinancieren, en mogen ze volgens de Claimcode geen marktconforme voorwaarden daarvoor bedingen, terwijl er, zoals hiervoor bleek, geen adequate andere financieringsalternatieven zijn. Het gevolg hiervan is ofwel dat er onvoldoende financieringsmogelijkheden zullen zijn voor legitieme collectieve acties, zodat geen concurrerende prijsvorming kan plaatsvinden, ofwel dat er minder professionele en ervaren partijen in de ontstane financieringsleemte zullen springen. Dat laatste zal uiteindelijk een negatief effect hebben op de uitstraling, kwaliteit en effectiviteit van collectieve acties. Professionele en ervaren financiers fungeren immers als een selectieportaal voor kwalitatief hoogwaardige claims. ${ }^{80,81}$ Als laatstgenoemden toch ertoe zouden besluiten om een collectieve actie te financieren, zullen ze, bij gebrek aan een concurrerende prijsvorming, hogere risico-opslagen bedingen en zal er minder overblijven voor benadeelden. Dat is evenmin een wenselijke ontwikkeling. Het is ook niet onwaarschijnlijk dat zij de collectieve actie helemaal links laten liggen en met het ook thans veelgebruikte cessiemodel zullen blijven werken. Het gevolg hiervan zal zijn dat de collectieve actie in onbruik raakt. Is dit te voorkomen?

\subsection{Het common fund}

Het freeriderprobleem van de ongerechtvaardigd gelijke behandeling van actieve en niet-actieve leden is niet beperkt tot Nederland. Andere jurisdicties ${ }^{82}$ met een opt-outregime hebben daar een relatief eenvoudige oplossing voor gevonden door toepassing van de zogenoemde 'common fund'-doctrine. Dat houdt in dat in het geval van een geslaagde collectieve actie en/of schikking de 'success fee' van de advocaat en/of de risico-opslag van de financier door de rechter bepaald worden op basis van het totale schikkingsbedrag, ook voor zover het vergoedingen betreft van de niet-actieve leden en ook al bestaat er geen contractuele relatie tussen hen en de financier en/of de belangenorganisatie. Op deze manier wordt ervoor gezorgd dat zowel de actieve als de niet-actieve leden die van het resultaat profiteren in gelijke mate financieel bijdragen aan de actie en de actieve leden 'niet gestraft worden' voor hun

80. Dat bleek ook uit de ervaringen in de veelbesproken Excalibur-zaak: Excalibur Ventures LLC v. Texas Keystone Inc and Ors (Rev 2) [2014] EWHC 3436, die gefinancierd werd door partijen die geen ervaring met procesfinanciering hadden en ook geen controle op de advocaten mochten uitoefenen. In hoger beroep werd door de Engelse rechter benadrukt dat de TPF controle op de procedure mocht uitoefenen en/of het gedrag van de advocaten moest monitoren, indien de advocaten niet op 'contingency fee' (maar op uurbasis) opereren: Excalibur Ventures LLP v. Texas Keystone Inc and others [2016] EWCA Civ 1144.

81. Zie ook Hensler 2014.

82. VS, Canada, Israël en Australië. activisme en 'barmhartige-samaritaanschap'. In de desbetreffende jurisdicties is de 'common fund'-doctrine ontwikkeld in de rechtspraak. Dat is in die jurisdicties die vooral op precedenten en case law-vorming steunen niet ongewoon. In de Nederlandse setting is het echter de vraag of een rechter, zonder inmenging van de wetgever, tot de ontwikkeling en toepassing van een dergelijke 'common fund'-doctrine zou kunnen overgaan. Het is daarom aan te bevelen om de mogelijkheid van deze wijze van berekening van de 'success fee' van de financier die op 'contingency fee'-basis opereert, en een oplossing realiseert voor de gehele groep, expliciet in de wet te regelen. Dat vereist op zijn beurt het openstellen van de mogelijkheid om bij collectieve acties de schadevergoeding cumulatief vast te stellen, omdat het uitrekenen, administreren en uitbetalen van de 'success fee' per individueel geval voor extra vertraging in de individuele uitbetalingen zullen zorgen. Dit zou tevens bij de huidige praktijk van de WCAM-afwikkeling aansluiten.

Een andere vraag is of de 'success fee' door de rechter moet worden bepaald en/of goedgekeurd, en zo ja, of dat aan het begin dan wel aan het einde van de procedure zou moeten gebeuren. Met betrekking tot de eerste vraag onderscheid ik twee stromingen: de Noord-Amerikaanse en de AustralischEuropese. In de VS en Canada, waar advocaten op 'full contingency fees' in opt-out-'class actions' opereren op basis van de instructie van een enkele cliënt, wordt ervan uitgegaan dat de rechter de plicht heeft om over de belangen van de afwezige groepsleden te waken. Het is om die reden dat daar de rechter ook de 'success fee' van de advocaat-financier vaststelt. Hiertegenover staat de Australisch-Europese benadering, waar het uitgangspunt is dat financiële afspraken een contractuele kwestie tussen partijen betreft, waarin de rechter geen rol hoort te spelen. In een setting waarin opt-out in feite een optinactie is ${ }^{83}$ is dat minder verwonderlijk: er zijn echte cliënten die de afspraken met de advocaten en/of belangenorganisaties en/of funders monitoren en daar iets van kunnen vinden. Ook de Wet collectieve afwikkeling massaschade (WCAM) beschikt overigens niet over een bepaling die verlangt dat de rechter de 'success fees' van de belangenorganisaties en/of de financiers dient goed te keuren. Als partijen de rechter hierover niet informeren, daartoe niet verzoeken en de financiële afspraken met de belangenorganisaties buiten de verbindend te verklaren overeenkomst houden, dan ontbreekt in de WCAM thans een wettelijke grondslag om partijen daartoe te

83. Voor een lezenswaardige bespreking van het Australische systeem en de ontwikkeling van de Australische opt-out-'class action' tot opt-in, vanwege de financieringsperikelen, zie C. Cameron, Litigation as 'core business': Analyzing the access to justice and regulatory dimensions of commercially funded class actions in Australia, in: D.R. Hensler, Ch. Hodges \& I.N. Tzankova (red.), Class actions in context, Cheltenham, Edward Elgar Publishing 2016, p. 189-211 en V. Waye \& V. Morabito, When pragmatism leads to unintended consequences: A critique of Australia's unique closed class regime, Theoretical Inquires in Law, nog niet gepubliceerd. Voor wat betreft het Nederlandse systeem: ik legde hiervoor voor het Nederlandse rechtssysteem al uit waarom de eis van representativiteit het opt-outmodel in het wetsvoorstel in feite tot een opt-inmodel verandert. 
verplichten. In het afgelopen jaar is echter zowel in Australië ${ }^{84}$ als in Nederland ${ }^{85}$ een trend waarneembaar, waarin de rechter hierin een actievere houding aanneemt. Het wetsvoorstel anticipeert niet op deze trend: eisende partijen moeten in het kader van de beoordeling van hun ontvankelijkheid kunnen aantonen dat zij de financiële lasten van een collectieve actie kunnen dragen, maar daar blijft het bij. In het licht van de bijzondere aard van collectieve acties en de recente trends in ervaren jurisdicties verdient dit een heroverweging, mits tegelijkertijd ook de 'common fund'-doctrine zou worden ingevoerd. Als de hiervoor bedoelde aanscherping van de rechterlijke rol (ook in het kader van de WCAM) zou plaatsvinden zonder een gelijktijdige invoering van de 'common fund'-doctrine, zou het collectieve-actierecht nog onaantrekkelijker voor procesfinanciers worden dan in het huidige voorstel al het geval is. Het gaat om een tweetrapsraket.

Dan is er nog de vraag op welk moment de bepaling van de 'success fee' over een eventueel 'common fund' het meest aangewezen is. Het bepalen van de 'success fee' aan het begin van een procedure, als iedereen nog vers en onbevangen in de procedures en risico's zit, zou wellicht tot een meer realistische indicatie kunnen leiden: achteraf is het altijd makkelijker praten dat het meeviel met het risico. Een ander voordeel is dat de financier in een vroeg stadium duidelijkheid heeft over de economische parameters van de acties en zich tijdig terug zou kunnen trekken als deze niet bevallen en/of niet als marktconform worden ervaren. Dat heeft als nadeel dat op de rechter grote verantwoordelijkheid komt te liggen en de vraag is of de rechter die wel kan en/of wil dragen. Een vaststelling van de 'success fee' achteraf zou meer rekening kunnen houden met hoe de actie is afgelopen, wat zij de groep heeft gebracht, hoe groot de groep was die uiteindelijk van de oplossing heeft geprofiteerd, hoelang de procedure geduurd heeft, de kwaliteit van procederen, de moeite die eisers hebben moeten doen om het procesgedrag van verweerders te adresseren, enzovoort. Daardoor duurt de onzekerheid bij de financier wel langer, maar wordt de rechter niet gevraagd om 'kleur' te bekennen. Door zich aan het begin uit te moeten laten over de hoogte van de 'success fee' zou de rechter indirect een oordeel moeten geven over de kansen van de procedure. Omgekeerd, als de rechter ziet dat een ervaren financier een relatief gezien lage of hoge 'success fee' heeft afgesproken, zou dat de rechter kunnen beïnvloeden in zijn visie over de kansen van de actie? Een tussenweg zou kunnen zijn dat de rechter de 'success fee' op voorwaardelijke basis goedkeurt als die binnen de gangbare commerciële bandbreedtes valt, en de bevoegdheid heeft om deze gemotiveerd achteraf bij te stellen.

Voor de goede orde wijs ik erop dat het bovenstaande niet meebrengt dat commerciële procesfinanciering de enige manier is om collectieve acties mogelijk te maken. Er zijn

84. Money Max Int Pty Ltd v. QBE [2016] FCAFC 148.

85. In de Fortis-tussenbeschikking neemt het Hof Amsterdam een actieve houding aan ten aanzien van de financiële afspraken ten gunste van de belangenorganisaties-financiers. meerdere wegen die naar Rome leiden, maar zij hebben allemaal een adequate commerciële component en ze moeten er wel zijn: naast de hiervoor besproken procesfinanciering (Australië), zijn er nog 'contingency fees' (VS en Israël) en combinaties van 'full contingency fees' en een openbaar fonds (Canada en Israël). Omdat het opheffen van het verbod op 'full contingency fees' in Nederland buiten de macht van de wetgever ligt, is het nodig dat de houding van de wetgever met betrekking tot procesfinanciering in collectieve acties wijzigt van neutraal naar faciliterend, zoals hiervoor voorgesteld. De inherente asymmetrie in de financiële incentives en investeringsmogelijkheden tussen eisers en gedaagden in gevallen van massaschade en de structurele achterstelling en/of de financiële disbalans ten nadele van benadeelden van gevallen van massaschade vormen hier een extra argument voor, evenals artikel 6 EVRM en de beginselen van equality of arms en effectieve rechtsbescherming.

\subsection{Gerichte rechterlijke training}

Het systeem van de ebb en de toepassing van de 'common fund'-doctrine (indien ingevoerd) vereisen vaardigheden van de Nederlandse rechter waarmee hij/zij vooralsnog onbekend is en waarbij hij/zij zich mogelijk ongemakkelijk voelt. Een gerichte rechterlijke training daarin is geen overbodige luxe en ook niet onoverkomelijk, mits rechters inzicht hebben in en begrip hebben voor de financieringsuitdagingen van belangenorganisaties en affiniteit hebben met financieel-economische vraagstukken. Dat zal niet voor alle rechters het geval zijn en het wetsvoorstel doet er dan ook goed aan dat het de behandeling bij één rechtbank concentreert. Verder is het een kwestie van gewenning, ervaring opdoen en ervaringen met (buitenlandse) collega's uitwisselen. De aanwijzing van een curator in een faillissement is tot op zekere hoogte vergelijkbaar met de aanwijzing van een ebb: ook daar moet de rechter beoordelen welke curator het beste past bij een betreffend faillissement, en heeft hij daar in de loop der jaren criteria voor ontwikkeld. Recentelijk nog moest ook de Duitse rechter in de VW-beleggingszaak de testcase en de bijbehorende advocaten selecteren ${ }^{86}$ en dat doet hij in het kader van de KapMug ${ }^{87}$ sinds 2005. Niet valt in te zien waarom de Nederlandse rechter, die internationaal veel aanzien geniet, daar niet in zou slagen, nu deze ook in staat is om complexe internationale handelsgeschillen in het Engels te beslechten. De concentratie bij één gerecht vergemakkelijkt, zoals gezegd, een gerichte training en het opbouwen van expertise. Het zorgt ervoor dat het spreekwoordelijke wiel niet steeds uitgevonden hoeft te worden, en dat een systeem van 'good practices' wordt opgebouwd ook met betrekking tot de risicowaardering en adequate beloning van enterpreneurial lawyering. ${ }^{88}$ Degelijke rechterlijke training is van een extra groot belang in een setting, waarin het debat

86. Zie frtservices.com/case-spotlight-volkswagen-shareholder-class-action/. 87. Kapitalanleger-Musterverfahrensgesetz.

88. Zie bijv. ook de Manual for Complex Litigation, Fourth, $\$ 22$ van de US Federal Judicial Center, deel 21: public.resource.org/scribd/ 8763868.pdf. Zie ook I.N. Tzankova, Case management: The stepchild of mass claim dispute resolution, Uniform Law Review (19) 2014. afl. 3, p. 329-350. 
over adequate commerciële incentives onderontwikkeld is en/ of eenzijdig wordt gevoerd, zoals hiervoor in paragraaf 2.3 werd toegelicht.

Het verdient in dat kader ook aanbeveling om de registratieplicht in het wetsvoorstel aan het begin van een collectieve actie $^{89}$ uit te breiden met rapportageplichten aan het einde van de procedure. Dat zal beleidsmakers en het publiek zicht geven in de (on)zin van collectieve acties, waardoor evenwichtige evidence based discussies en wetgeving mogelijk zullen zijn naar aanleiding van vragen als: in wat voor gevallen worden collectieve acties ingezet; wat hebben zij partijen gekost (eisers, gedaagden, de collectieve procedure en/of de collectieve schikking); wat hebben zij benadeelden opgeleverd; hebben zij gedragsverandering tot gevolg gehad; hoe groot was de groep die uiteindelijk van de actie geprofiteerd heeft; hoelang hebben de procedures geduurd; en hoeveel rechterlijke tijd is erin gaan zitten? Het zijn zaken die relatief eenvoudig te rapporteren zouden moeten zijn, maar die thans zelfs ten aanzien van de WCAM ontbreken. ${ }^{90}$ Dat laatste zou dan ook meteen kunnen worden meegenomen.

\section{Conclusie}

Het wetsvoorstel werd ingevoerd als gevolg van de motie Dijksma, die de onderhandelingsbereidheid van verweerders moest vergroten en de positie van belangenorganisaties in collectieve schadevergoedingsacties moest verbeteren. Het momentum werd door een samenwerkende lobby van de meer gevestigde belangenbehartigers en advocaten van verweerders aangegrepen om tevens een tweetal knelpunten van de huidige regeling te adresseren: de concurrerende belangenorganisaties met twijfelachtige governance en het bereiken van finaliteit bij de massaschadeafwikkeling. Deze operatie lijkt geslaagd, maar of de patiënt het overleefd heeft, valt nog te bezien. Terwijl het systeem van de ebb in combinatie met het voorgestelde optoutregime vroeg in de procedure verweerders een grote dienst bewijst en hen faciliteert in hun wens naar stroomlijning en finaliteit, doet het wetsvoorstel weinig voor de adequate financiering van collectieve acties. De beschikbare financieringsopties schieten tekort en één van de paar mogelijkheden die nog wel beschikbaar zijn, is die van commerciële procesfinanciering. Of deze na de introductie van het wetsvoorstel in voldoende mate beschikbaar blijft, is echter onzeker. Het anticommerciesentiment in relatie tot privaatrechtelijke handhaving, mede als gevolg van de sterke 'anti-class actions'-lobby van de Chamber op Europees niveau, lijkt hier debet aan. Het door het wetsvoorstel niet-geadresseerde freeriderprobleem zal tot gevolg hebben dat er onvoldoende financieringsmogelijkheden zullen zijn voor legitieme collectieve acties. Voor zover er mogelijkheden zijn, zal geen concurrerende prijsvorming kunnen plaatsvinden en/of zullen minder professionele en

89. Collectieve acties moeten worden geregistreerd in een register ten behoeve van het bepalen van de ebb: art. 3:305a lid 7 BW.

90. Over de wenselijkheid van een dergelijke rapportageplicht, zie ook D. Ozmis \& I.N. Tzankova, De evaluatie van de WCAM: de kernthema's uitgelicht, TCR 2012, afl. 2, p. 33-42. ervaren partijen in de ontstane financieringsleemte springen. Dat zal een negatief effect hebben op de uitstraling van collectieve acties en op de toegang tot het recht voor benadeelden. Het is ook denkbaar dat de collectieve actie in onbruik raakt. Ik heb ervoor gepleit om dit te ondervangen door een wettelijke introductie van de 'common fund'-doctrine, gekoppeld aan de bevoegdheid voor de rechter om zowel in het kader van collectieve acties als in het kader van collectieve schikkingen (waaronder ook de WCAM) de 'success fee' voor de procesfinanciers te bepalen. Dit dient te worden geflankeerd door een passende opleiding en training van de rechters die over collectieve acties gaan oordelen. Ook dient de registratieplicht te worden uitgebreid met rapportageplicht aan het einde van een collectieve actie en/of schikking, zodat een dataset kan worden gevormd die ten dienste kan staan aan een evidence based beleidsvorming op dat terrein. Het wetsvoorstel introduceert oplossingen voor een aantal problemen in de huidige collectieve-actiepraktijk, maar of het ook tot realisatie van de doelstellingen van de motie Dijksma gaat leiden, waarmee dit alles begon? Ik durf dat te betwijfelen. 